\title{
DESAIN KONTROL MULTI - INPUT DC - DC CONVERTER SISTEM HIBRID TURBIN ANGIN DAN SEL SURYA MENGGUNAKAN KONTROL FUZZY LOGIC UNTUK TEGANGAN RENDAH
}

\author{
Feby Agung Pamuji ${ }^{1}$ dan Soedibyo ${ }^{2}$ \\ ${ }^{1}$ Jurusan Teknik Elektro, Fakultas Teknologi Industri, Institut Teknologi Sepuluh Nopember \\ ${ }^{2}$ Program Studi Sistem Tenaga, Fakultas Teknologi Industri, Institut Teknologi Sepuluh Nopember \\ febyagungpamuji@gmail.com,dibyosoe@gmail.com
}

\begin{abstract}
Abstrak-Dalam makalah ini diuraikan sistem hibrid yang menggabungkan Turbin Angin dan Photovoltaic untuk memasok listrik terus-menerus pada beban. Output dari Turbin Angin dan Photovoltaic diatur agar menghasilkan daya yang maksimum. Konverter multiple-input buck-boost dc-dc digunakan untuk mengatur aliran daya agar didapatkan MPP(Maximum Power Point). Kontrol konverter menggunakan Fuzzy Logic controller untuk mengkontrol output sehingga didapat MPP(Maximum Power Point) dari Turbin Angin dan Photovoltaic, sehingga effisiensi dari Turbin Angin dan Photovoltaic dapat ditingkatkan.
\end{abstract}

Kata Kunci : Maximum Power Point, system hibrid, Fuzzy Logic controller

\begin{abstract}
Wind Turbines and Photovoltaic to supply electricity continuously for load. Output of Wind Turbines and Photovoltaic is controlled in order to generate maximum power. Multiple-input dc-dc converters is used to control power flow in order to have MPP (Maximum Power Point). Converter control using Fuzzy logic controller to control the output in order to be obtained MPP (Maximum Power Point) from Wind Turbines and Photovoltaic, so the efficiency of wind turbines and photovoltaic can be improved.
\end{abstract}

Keywords : Maximum Power Point, Hybrid System, Fuzzy logic controller

\section{PENDAHULUAN}

Sehubungan semakin menipisnya energi fosil dan banyaknya pencemaran lingkungan, membuat teknologi pembangkit listrik energi terbarukan seperti sel surya dan turbin angin semakin berkembang. Pembangkit listrik energi terbarukan pada berbagai lokasi dapat diintegrasikan dalam sistem distribusi yang dikenal dengan istilah pembangkit tersebar (distributed generation, DG). Integrasi distributed generation dalam sistem distribusi dapat mengurangi rugi - rugi daya dan jatuh tegangan. Dalam integrasi distributed generation, persoalan penting yang harus diperhatikan adalah bagaimana menentukan lokasi, kapasitas dan jumlah pembangkit serta teknologi yang digunakan.

Ada beberapa cara untuk meminimalkan rugi-rugi sistem distribusi daya listrik dalam rangka meningkatkan efisiensi sistem di antaranya rekonfigurasi jaringan, pemasangan kapasitor, penyeimbangan beban, dan meningkatkan aras tegangan listrik menggunakan regulator. Cara pemasangan kapasitor pada jaringan dan penyeimbangan beban biasanya mengalami kesulitan karena beban sistem distribusi yang sangat dinamis. Dengan demikian nilai kapasitansi kapasitor harus selalu berubah dari waktu ke waktu dan beban harus dibuat seimbang. Sedangkan cara meminimalkan rugi-rugi dengan meningkatkan harga tegangan listrik memerlukan biaya yang besar karena seluruh peralatan yang terhubung dengan sistem ini harus mampu bekerja pada tegangan yang baru, sementara hasilnya belum tentu berhasil. Oleh karena itu diusulkan suatu gagasan desain kontrol Multi - Input DC - DC Converter Sistem Hibrid Turbin Angin dan Sel Surya menggunakan fuzzy logic untuk tegangan rendah untuk meningkatkan efisiensi, keandalan dan stabilitas pada sistem distributed generation energi terbarukan surya dan angin yang optimal. Sistem pada penelitian ini hanya difokuskan pada pembuatan kontrol Multi - Input DC - DC menggunakan fuzzy logic dan merupakan 
keberlanjutan dari penelitian atau thesis sebelumnya yang hanya sampai pada simulasi sistem.

\section{TINJAUAN PUSTAKA}

\subsection{Sel Surya}

Energi radiasi surya dapat diubah menjadi arus listrik searah dengan mempergunakan lapisan-lapisan tipis dari silicon $(\mathrm{Si})$ murni atau bahan semi konduktor lainnya. saat ini silicon merupakan bahan yang terbanyak dipakai. Susunan PV adalah sel surya, yang mana dasarnya sebuah semikonduktor p-n. Karakteristik Arus-Tegangan(I-V) dari solar photovoltaic seperti persamaan(1) dibawah [1].

$I_{P V}=n_{p} I_{S C}-n_{p} I_{o}\left\{\exp \left[\frac{q\left(V_{P V}+R_{S} P_{V}\right)}{A k T n_{S}}\right]-1\right\}-n_{p} \frac{\left(V_{P V}+R_{s} I_{P V}\right)}{n_{s} R_{S h}}$

Dimana $V_{P V}$ dan $I_{P V}$ menunjukkan keluaran tegangan dan arus dari sel surya, berurutan; $R_{S}$ dan $R_{s h}$ adalah seri dan hambatan shunt dari sel; $q$ adalah muatan elektron $\left(1.6 e^{-19} C\right) ; I_{S C}$ adalah arus yang dibangkitkan cahaya; $I_{o}$ arus reverse saturasi; $A$ adalah factor sambungan material yang berdimensi; $k$ adalah konstanta Boltzmann $\left(1.3 e^{-23} \mathrm{~J} / K\right) ; T$ adalah temperatur $(K) ; n_{p}$ dan $n_{s}$ adalah jumlah sel -sel yang dikoneksi parallel dan seri berurutan [1].

\subsection{Turbin Angin}

Angin adalah udara bergerak yang terjadi karena pemanasan tidak merata oleh matahari terhadap permukaan bumi. Gerakan udara adalah energi kinetik angin yang dapat dimanfaatkan untuk berbagai keperluan, seperti penggerak generator pembangkit listrik melalui sistem konversi dengan turbin angin. Jumlah daya angin yang ditangkap turbin tergantung kepada ukuran baling-baling turbin dan kecepatan angin, dapat dinyatakan dalam bentuk persamaan sebagai berikut :

$$
P_{w t}=\frac{1}{2} \pi R^{2} \rho v^{3}
$$

$R$ adalah jari-jari turbin angin, $\rho$ densitas udara dan $v$ kecepatan angin. Daya mekanik yang dihasilkan turbin ditentukan oleh efisiensi turbin angin, yang dirumuskan dengan persamaan :

$$
P_{m}=\frac{1}{2} \eta \pi \rho R^{2} v^{3}
$$

Berdasarkan Bezt limit, efisiensi turbin angin maksimum adalah 0.57 . Nilai efisiensi ini ditentukan oleh koefisien daya dan Tip Speed Ratio (TSR) [5]. Koefisien daya adalah rasio daya mekanik pada turbin dengan daya angin yang ditangkap oleh baling-baling turbin dan TSR merupakan rasio kecepatan baling-baling turbin dengan kecepatan angin, yang dijabarkan dalam persamaan :

$$
\begin{aligned}
& C_{p}=\frac{P_{m}}{P_{w t}} \\
& \lambda=\frac{\omega_{w} R}{v}
\end{aligned}
$$

$C_{p}$ adalah Koefisien daya , $\lambda$ Tip Speed Ratio (TSR) dan $\omega_{w}$ merupakan kecepatan angular turbin.Hubungan antara daya mekanik dengan koefisien daya dan TSR dijabarkan dalam persamaan:

$$
P_{m}=\frac{1}{2} \pi \rho C_{p}(\lambda, \beta) R^{2} v^{3}
$$

$\beta$ merupakan sudut baling-baling turbin terhadap arah angin. Daya mekanik merupakan daya yang akan ditransfer ke generator. Nilai koefisien daya ditentukan oleh TSR dan sudut baling-baling turbin. Hubungan antara TSR, koefisien daya dan sudut baling-baling turbin dinyatakan dengan persamaan:

$C_{p}(\lambda, \beta)=c_{1}\left(\frac{c_{2}}{\lambda_{i}}-c_{3} \beta-c_{4}\right) e^{\frac{-c_{5}}{\lambda_{i}}}+c_{6} \lambda$

Dengan

$$
\frac{1}{\lambda_{i}}=\frac{1}{\lambda+0.08 \beta}-\frac{0.035}{\beta^{3}+1}
$$

$c_{1}$ sampai $c_{2}$ merupakan konstanta. Nilai TSR ditentukan oleh kecepatan putaran turbin dan kecepatan angin. Nilai koefisien daya dan TSR bervariasi pada satu kecepatan angin, tergantung kepada putaran turbin. Torka mekanik yang digunakan untuk memutar generator ditentukan oleh kecepatan putaran turbin dan daya mekanik turbin, yang dijabarkan dengan persamaan :

$$
T_{m}=0.5 \pi \rho C_{p} \beta R^{2} v^{3}
$$


Pada turbin angin yang menggunakan gearbox, daya dan torka mekanik pada poros generator adalah:

$$
\begin{gathered}
P_{m}=\omega_{m} \frac{T_{\text {shaft }}}{\eta_{\text {gear }}} \\
T_{m}=\frac{T_{\text {shaft }}}{\eta_{\text {gear }}}
\end{gathered}
$$

$\omega_{m}=\omega_{m} \eta_{\text {gear }}$

$T_{\text {shaft }}$ adalah torka mekanik pada poros kecepatan rendah, $T_{m}$ torka mekanik pada poros generator, $\omega_{w}$ kecepatan angular turbin, $\omega_{m}$ kecepatan mekanik poros generator dan $\eta_{\text {gear }}$ efisiensi gearbox.

\section{METODOLOGI ATAU TEORI}

\section{Karakteristik Photovoltaic (PV) dan Turbin Angin}

Plot karakteristik PV menggunakan diagram berikut:

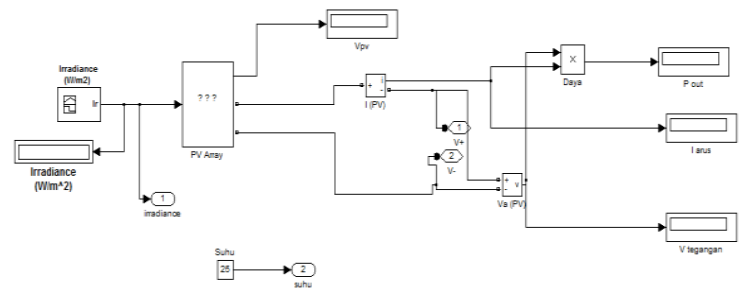

Gambar 1. Diagram Blok Plot Karakteristik PV

\subsection{Karakteristik}
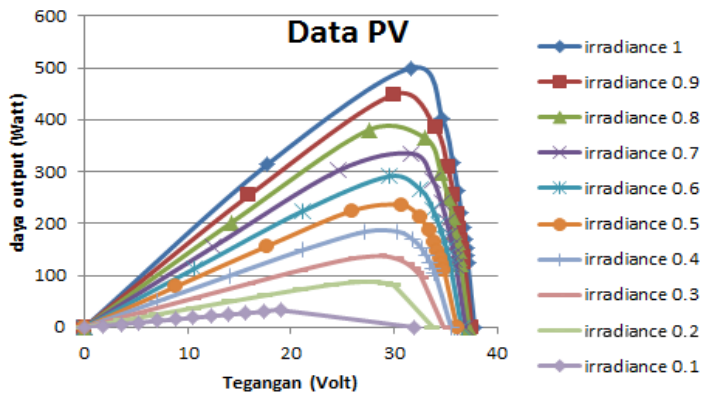

Gambar 2. Karakteristik PV

Dari grafik diatas diperoleh tegangan optimum tiap variasi Irradiance.
Tabel 1. Tegangan Optimum pada PV

\begin{tabular}{|c|c|c|c|}
\hline $\begin{array}{c}\mathrm{I} \text { (Arus) } \\
\mathrm{A}\end{array}$ & $\begin{array}{c}\text { Irradiance } \\
\mathrm{Kw} / \mathrm{m}^{2}\end{array}$ & $\begin{array}{c}\text { V(tegangan) } \\
\text { Volt }\end{array}$ & $\begin{array}{c}\mathrm{P} \text { (Daya) } \\
\text { Watt }\end{array}$ \\
\hline 15.81 & 1 & 31.61 & 499.6 \\
\hline 14.98 & 0.9 & 29.95 & 448.5 \\
\hline 13.8 & 0.8 & 27.59 & 380.7 \\
\hline 10.57 & 0.7 & 31.7 & 335.1 \\
\hline 9.852 & 0.6 & 29.56 & 291.2 \\
\hline 7.675 & 0.5 & 30.7 & 235.7 \\
\hline 6.072 & 0.4 & 30.36 & 184.4 \\
\hline 5.132 & 0.3 & 25.66 & 131.7 \\
\hline 3.122 & 0.2 & 28.1 & 87.73 \\
\hline
\end{tabular}

\subsection{Karakteristik Turbin Angin}

Plot karakteristik Turbin Angin menggunakan diagram berikut :

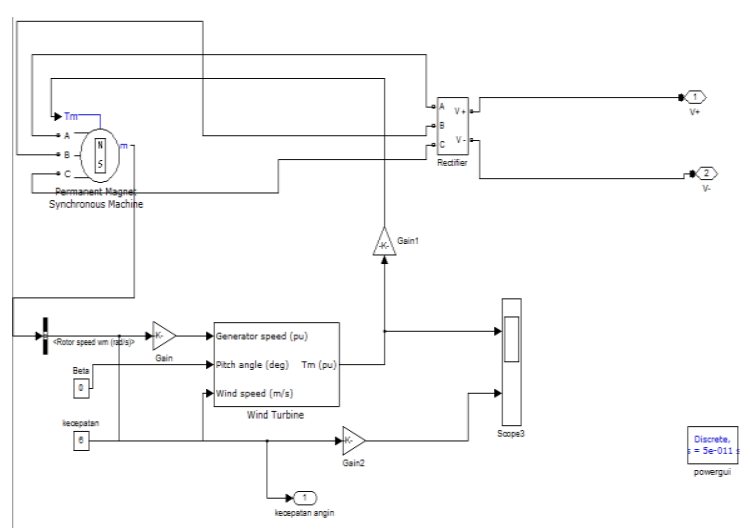

Gambar 3. Diagram Blok Plot Karakteristik Turbin Angin

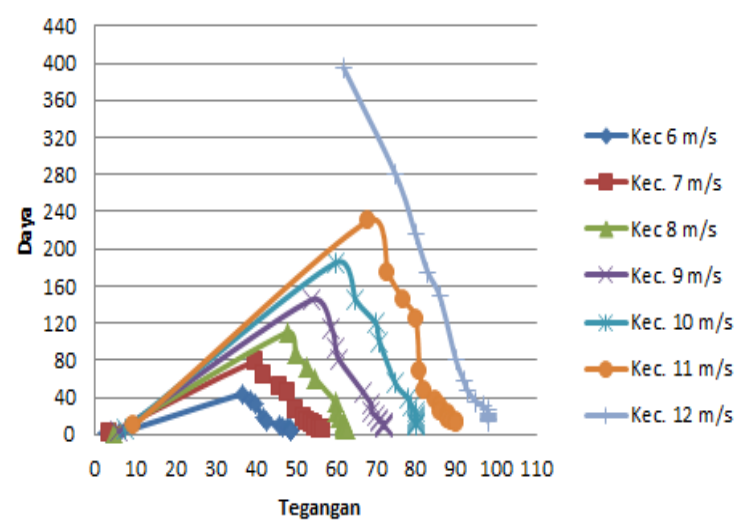

Gambar 4. Karakteristik Turbin Angin

Dari Gambar 4 diatas diperoleh tegangan optimum tiap variasi Kecepatan angin. 
Tabel 2.Tegangan Optimum pada Turbin Angin

\begin{tabular}{|c|c|c|c|}
\hline $\begin{array}{c}\text { Kecepatan } \\
\text { Angin (m/s) }\end{array}$ & $\begin{array}{c}\text { Arus } \\
\text { Optimum } \\
\text { (A) }\end{array}$ & $\begin{array}{c}\text { Tegangan } \\
\text { Optimum } \\
\text { (V) }\end{array}$ & $\begin{array}{c}\text { Daya } \\
\text { Optimum } \\
\text { (Watt) }\end{array}$ \\
\hline $6 \mathrm{~m} / \mathrm{s}$ & 1.2 & 37 & 44 \\
\hline $7 \mathrm{~m} / \mathrm{s}$ & 2 & 40 & 79 \\
\hline $8 \mathrm{~m} / \mathrm{s}$ & 2.4 & 48 & 110 \\
\hline $9 \mathrm{~m} / \mathrm{s}$ & 2.7 & 54 & 145 \\
\hline $10 \mathrm{~m} / \mathrm{s}$ & 3 & 60 & 185 \\
\hline $11 \mathrm{~m} / \mathrm{s}$ & 3.45 & 68 & 230 \\
\hline $12 \mathrm{~m} / \mathrm{s}$ & 6.2 & 62 & 395 \\
\hline
\end{tabular}

Karakteristik tegangan optimum Photovoltaic dan Tubin Angin diatas digunakan untuk desain Fuzzy Logic controller.

\subsection{Konfigurasi Sistem yang diusulkan 3.3.1 Multi-Input Konverter DC/DC}

Multi-input konverter yang diusulkan $\mathrm{dc} / \mathrm{dc}$ adalah perpaduan dari converter buckboost dan buck. Sintesis dari masukan-multi converter DC/DC dilakukan dengan memasukkan sumber tegangan berdenyut dari converter buck kedalam konverter buck-boost. Agar tidak menghambat operasi normal dari konverter buck-boost dan memanfaatkan induktor untuk konverter buck, sumber tegangan berdenyut dari konverter buck harus dihubungkan seri dengan induktor output.

Berdasarkan status konduksi dari switch $\mathrm{M}_{1}$ dan $\mathrm{M}_{2}$, konverter multi- input DC/DC memiliki empat mode operasi. Gambar. 7 (a) sampai (d) menunjukkan rangkaian ekivalen untuk Mode I sampai Mode IV. Ketika switch $M_{1}$ atau $M_{2}$ dimatikan, dioda $D_{1}$ dan $D_{2}$ akan memberikan jalan bebas berputar untuk arus induktor. Jika salah satu sumber tegangan gagal, tegangan lainnya masih dapat menyediakan energi listrik, dengan normal. Oleh karena itu, itu sangat cocok untuk aplikasi energi terbarukan.

Hubungan tegangan input-output dapat diturunkan dari analisis keseimbangan steadystate tegangan kedua dari induktor. Jika $\mathrm{M}_{1}$ memiliki waktu konduksi lebih lama dari $\mathrm{M}_{2}$, maka operasi rangkaian ekivalen untuk satu siklus switching akan mengikuti urutan dari Mode I, Mode III, dan Mode IV. Di sisi lain, jika $\mathrm{M}_{2}$ memiliki waktu konduksi lebih lama dari $\mathrm{M}_{1}$, urutan menjadi Mode II, Mode III, dan Mode IV. Dalam kedua kasus, tegangan output dapat dinyatakan sebagai:

$$
V_{D C}=\frac{d_{1}}{1-d_{2}} V_{P V}+\frac{d_{2}}{1-d_{2}} V_{W i n d}
$$

dimana $\mathrm{d}_{1}$ dan $\mathrm{d}_{2}$ adalah rasio duty dari switch $\mathbf{M}_{1}$ dan $\mathbf{M}_{2}$. Demikian pula, inputan rata-rata dan arus output dapat diperoleh:

$$
\begin{aligned}
& I_{1}=\frac{d_{1}}{1-d_{2}} I_{0} \\
& I_{2}=\frac{d_{2}}{1-d_{2}} I_{0}
\end{aligned}
$$

Dari persamaan tegangan steady-state dan persamaan-persamaan arus, tuntutan distribusi daya yang berbeda dari konverter multi-input DC/DC dapat dicapai.
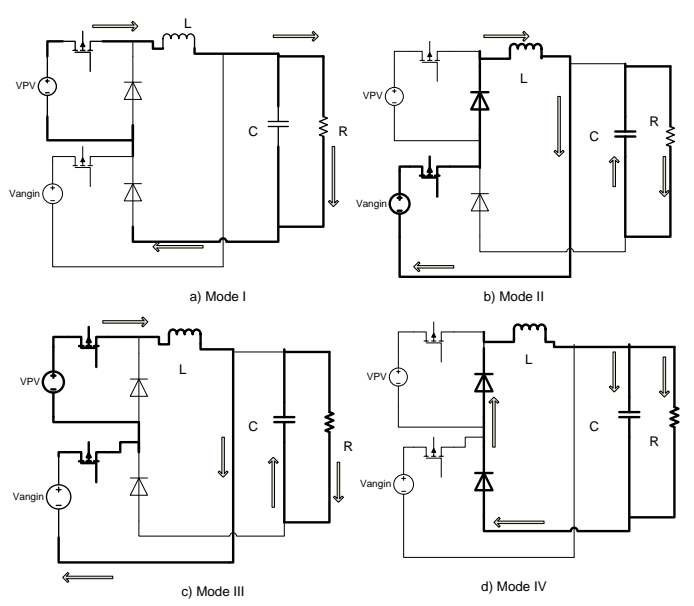

Gambar 5. Rangkaian-rangkaian ekuivalen untuk konverter multi input DC/DC.

\subsubsection{Desain control Fuzzy Logic Controller}

Fuzzy logic controller digunakan untuk mengkontrol Pulse wave modulation (PWM) untuk mengatur multi input DC/DC agar memperoleh daya optimum dari sel surya dan turbin angin. Desain fuzzy logic dapat dilihat pada gambar dibawah:

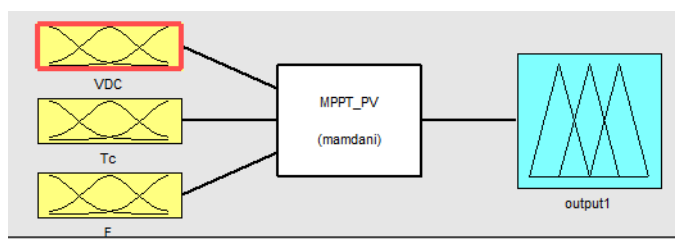

Gambar 6. Desain Fuzzy Logic untuk pengaturan sel surya. 
Pada desain diatas dapat dilihat fuzzy logic controller didesain terdiri dari 3 input dan satu output. Input VDC meprupakan input tegangan actual dari sel surya, sedangkan input Tc adalah input suhu cel dan $\mathrm{E}$ adalah input irradiance sedangkan outputnya adalah duty cycle. Membership function dari input dan output dapat dilihat dari gambar dibawah ini:

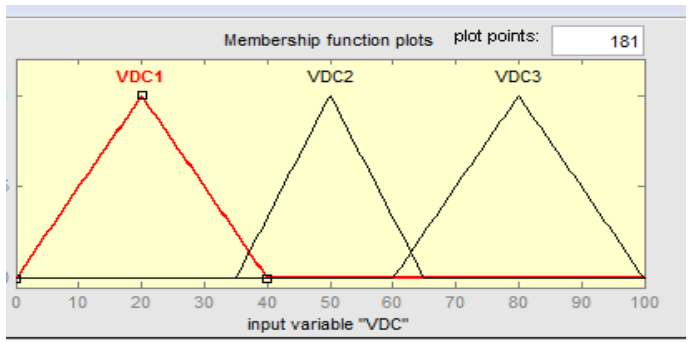

Gambar 7. Membership Function VDC.

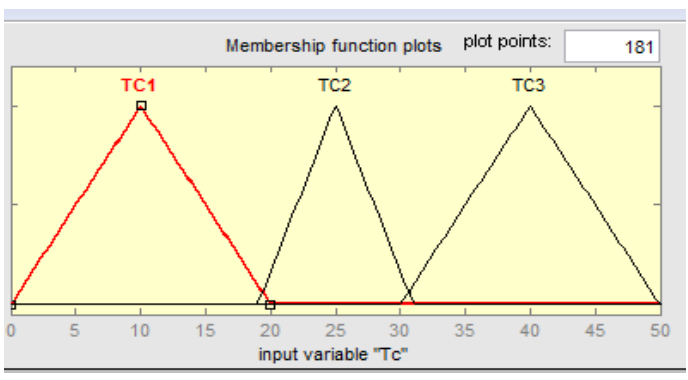

Gambar 8. Membership Function TC.

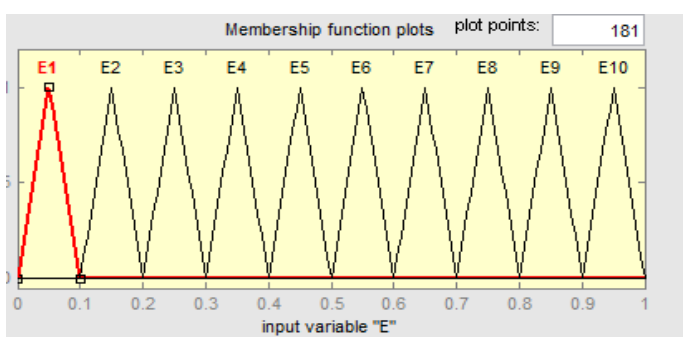

Gambar 9. Membership Function E.

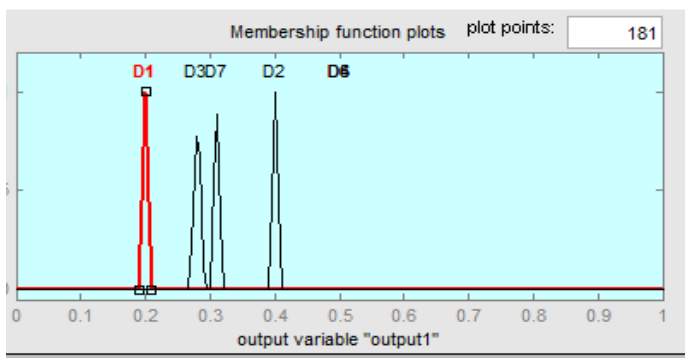

Gambar 10. Membership Function Output.
Dari membership function dari PV dapat dibuat rule Fuzzy logic controller seperti dibawah:

1. If (VDC is VDC1) and (Tc is TC1) and (E is E1) then (output1 is D1) (1) 2. If (VDC is VDC1) and (Tc is TC1) and (E is E2) then (output1 is D1) (1) 3. If (VDC is VDC1) and (TC is TC1) and (E is E3) then (output1 is D1) (1) 4. If (VDC is VDC1) and (TC is TC1) and (E is E4) then (output1 is D1) (1) 5. If (VDC is VDC1) and (TC is TC1) and (E is E5) then (output1 is D1) (1) 6. If $(V D C$ is VDC1) and (TC is TC1) and (E is E6) then (output1 is D1) (1) 7. If (VDC is VDC1) and (TC is TC1) and (E is E7) then (output1 is D1) (1) 8. If (VDC is VDC1) and (TC is TC1) and (E is E8) then (output1 is D1) (1) 9. If (VDC is VDC1) and (Tc is TC1) and (E is E9) then (output1 is D1) (1) 10. If (VDC is VDC1) and (Tc is TC1) and (E is E10) then (output1 is D1) (1)

11. If (VDC is VDC2) and (TC is TC2) and (E is E1) then (output1 is D1) (1) 12. If (VDC is VDC2) and (TC is TC2) and (E is E2) then (output1 is D2) (1) 13. If (VDC is VDC2) and (TC is TC2) and (E is $E 3$ ) then (output1 is D3) (1) 14. If (VDC is VDC2) and (Tc is TC2) and (E is E4) then (output1 is D4) (1) 15. If (VDC is VDC2) and (TC is TC2) and (E is E5) then (output1 is D5) (1) 16. If (VDC is VDC2) and (Tc is TC2) and (E is E6) then (output1 is D6) (1) 17. If $(V D C$ is VDC2) and (TC is TC2) and ( $E$ is E7) then (output1 is D7) (1) 18. If (VDC is VDC2) and (Tc is TC2) and (E is E8) then (output1 is D7) (1) 19. If (VDC is VDC2) and (TC is TC2) and (E is E9) then (output1 is D7) (1) 20. If (VDC is VDC2) and (TC is TC2) and (E is E10) then (output1 is D7) (1)

21. If (VDC is VDC3) and (TC is TC2) and (E is E1) then (output1 is D1) (1) 22. If (VDC is VDC3) and (TC is TC2) and (E is E2) then (output1 is D1) (1) 23. If (VDC is VDC 3) and (TC is TC2) and (E is E3) then (output1 is D1) (1) 24. If (VDC is VDC3) and (TC is TC2) and (E is E4) then (output1 is D1) (1) 25. If (VDC is VDC3) and (TC is TC2) and (E is E5) then (output1 is D1) (1) 26. If (VDC is VDC3) and (Tc is TC2) and (E is E6) then (output1 is D1) (1) 27. If (VDC is VDC 3) and (TC is TC2) and (E is E7) then (output1 is D1) (1) 28. If (VDC is VDC3) and (TC is TC2) and (E is E8) then (output1 is D1) (1) 29. If (VDC is VDC1) and (TC is TC2) and (E is E1) then (output1 is D1) (1) 30. If (VDC is VDC1) and (Tc is TC2) and (E is E2) then (output1 is D1) (1)

31. If (VDC is VDC1) and (Tc is TC2) and (E is E3) then (output1 is D1) (1) 32. If (VDC is VDC1) and (TC is TC2) and (E is E4) then (output1 is D1) (1) 33. If (VDC is VDC1) and (TC is TC2) and (E is E5) then (output1 is D1) (1) 34. If (VDC is VDC1) and (TC is TC2) and (E is E6) then (output1 is D1) (1) 35. If (VDC is VDC1) and (TC is TC2) and (E is E7) then (output1 is D1) (1) 36. If (VDC is VDC1) and (TC is TC2) and (E is E8) then (output1 is D1) (1) 37. If (VDC is VDC1) and (TC is TC2) and (E is E9) then (output1 is D1) (1)

Untuk Desain fuzzy logic untuk mengatur turbin angin dapat dilihat pada gambar dibawah:

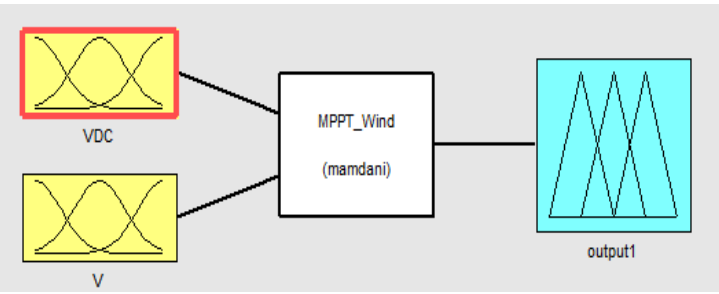

Gambar 11. Desain Fuzzy Logic untuk pengaturan Turbin Angin.

Pada desain diatas dapat dilihat fuzzy logic controller didesain terdiri dari 2 input dan satu output. Input VDC meprupakan input tegangan actual dari turbin angin, sedangkan input $\mathrm{V}$ adalah kecepatan angin sedangkan outputnya adalah duty cycle. Membership function dari input dan output dapat dilihat dari gambar dibawah ini: 


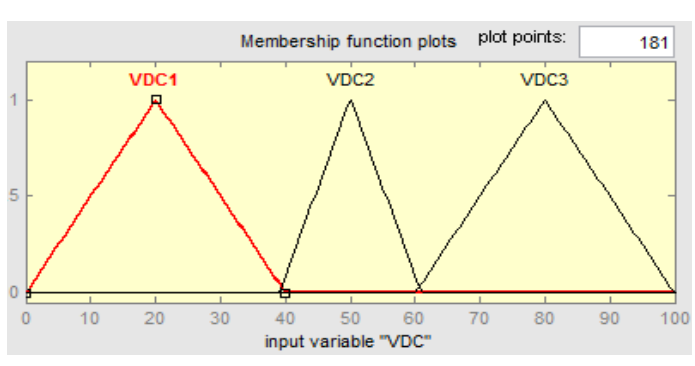

Gambar 12. Membership Function VDC.

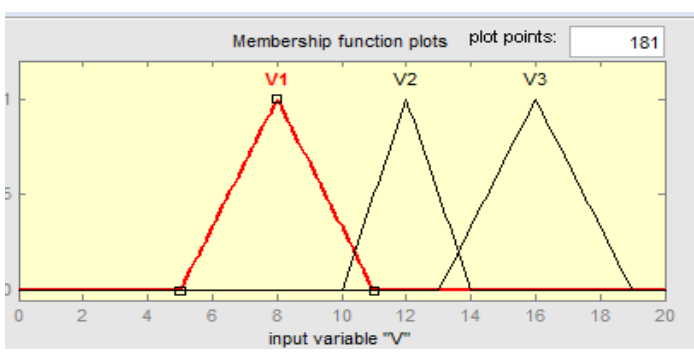

Gambar 13. Membership Function V.

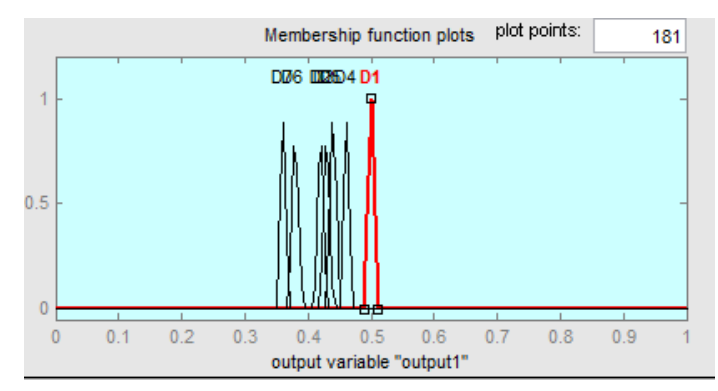

Gambar 14. Membership Function Output.

Dari membership function dari Turbin Angin dapat dibuat rule Fuzzy logic controller seperti dibawah:

1. If (VDC is VDC1) and (V is V1) then (output1 is D1) (1) 2. If (VDC is VDC1) and ( $V$ is V1) then (output1 is D2) (1) 3. If (VDC is VDC1) and ( $V$ is V1) then (output1 is D3) (1) 4. If (VDC is VDC1) and $(V$ is V1) then (output1 is D4) (1) 5. If (VDC is VDC1) and ( $V$ is $V 2$ ) then (output1 is D5) (1) 6 . If (VDC is VDC1) and ( $V$ is $V 2$ ) then (output1 is D6) (1) 7. If (VDC is VDC1) and ( $V$ is $V 2$ ) then (output1 is D7) (1) 8. If (VDC is VDC2) and ( $V$ is V1) then (output1 is D1) (1) 9. If (VDC is VDC2) and ( $V$ is $V 1$ ) then (output1 is D2) (1) 10. If (VDC is VDC2) and ( $V$ is V1) then (output1 is D3) (1) 11. If (VDC is VDC2) and ( $V$ is $V 1$ ) then (output1 is $D 4$ ) (1) 12. If (VDC is VDC2) and ( $V$ is $V 1$ ) then (output1 is D5) (1) 13. If (VDC is VDC2) and (V is V1) then (output1 is D6) (1) 14. If (VDC is VDC2) and $(V$ is V1) then (output1 is D7) (1) 15. If (VDC is VDC2) and $(V$ is $V 2$ ) then (output1 is $D 1$ ) (1) 16. If (VDC is VDC2) and $(V$ is $V 2$ ) then (output1 is D2) (1) 17. If $(V D C$ is VDC2) and $(V$ is $V 2$ ) then (output1 is D3) (1) 18. If (VDC is VDC2) and $(V$ is $V 2$ ) then (output1 is $D 4$ ) (1) 19. If (VDC is VDC2) and $(V$ is $V 2$ ) then (output1 is D5) (1) 20. If (VDC is VDC2) and ( $V$ is $V 2$ ) then (output1 is D6) (1) 21. If (VDC is VDC2) and $(V$ is $V 2$ ) then (output1 is $D 7)$ (1) 22 . If (VDC is VDC 3 ) and ( $V$ is $V 1$ ) then (output1 is D1) (1) 23. If (VDC is VDC3) and $(V$ is $V 2$ ) then (output1 is D1) (1) 24. If (VDC is VDC3) and (V is V3) then (output1 is D1) (1)

\section{HASIL DAN PEMBAHASAN}

Dalam simulasi ini digunakan software MATLAB 2010 mensimulasikan desain kontrol multi input DC - DC converter sistem hibrid angin dan surya menggunakan fuzzy logic.

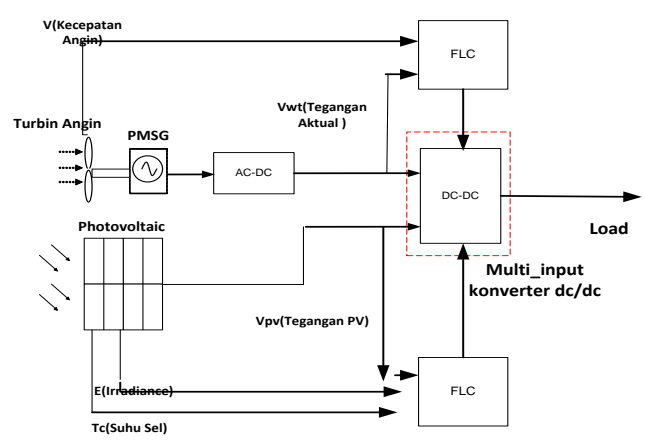

Gambar 15. Simulasi Desain Kontrol DC - DC Konverter Sistem Hibrid Tenaga Angin dan Sel

Surya Menggunakan Fuzzy Logic untuk

Tegangan Rendah dengan MATLAB 2010

Sistem Hibrid terdiri dari Photovoltaic (PV) dan Turbin Angin (TA) yang dihubungkan dengan beban, kontroler MPPTnya menggunakan Fuzzy Logic Controller yang mana inputan $F L C$ adalah E(Irradiance), VDC (Tegangan aktual) dan $\mathrm{Tc}($ suhu sel) untuk Photovoltaic (PV) sedangkan untuk Turbin Angin (TA) inputan Fuzzy Logic Controllernya adalah v(kecepatan angin) dan VDC (Tegangan aktual). Fuzzy Logic Controller berfungsi mencari Duty Cycle dari PWM untuk mengkontrol Multi-input Buck-boost untuk menggeser tegangan aktual ke tegangan optimum.

Hasil dari simulasi system hybrid dapat dilihat dibawah:

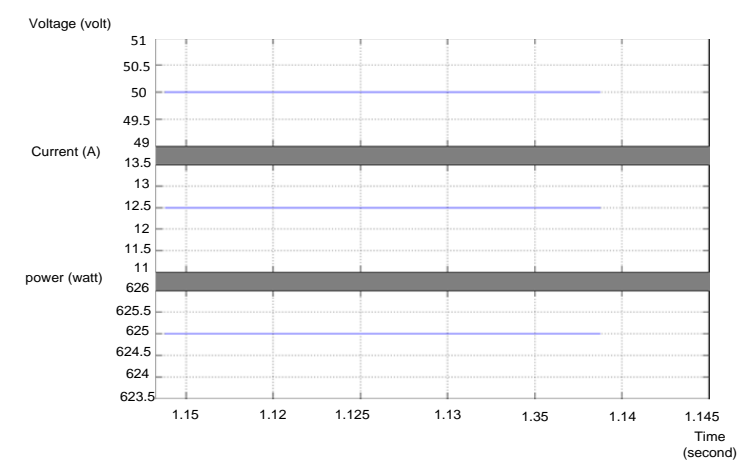

Gambar 16. Hasil simulasi system hybrid sel surya dan turbin angin. 
Dari hasil diatas pada kecepatan angin 12 $\mathrm{m} / \mathrm{s}$ dan irradiance $800 \mathrm{watt} / \mathrm{m}^{2}$ sistem hybrid dapat menghasilkan daya 625 watt pada kondisi daya jumlah maksimum sel surya dan turbin angin 894 watt.

\section{KESIMPULAN}

Sistem hybrid menggunakan multi input DC/ DC yang dikontrol dengan menggunakan Fuzzy Logic Controller dapat menghasilkan daya pada kondisi maksimum dari daya maksimum sel surya dan turbin angin sehingga losses pada sel surya dan turbin angin dapat diperkecil.

\section{DAFTAR PUSTAKA}

[1] Nabil A.A, Masafumi Miyatake,A.K.AlOthman, Power Fluctutions Suppression Of Stand-Alone Hybrid Generation Combining Solar Photovoltaic/Wind Turbine And Fuel Cell, Science Direct (2008).

[2] Syafaruddin,Engin Karatepe,Takashi Hiyama, Polar Coordinated Fuzzy Controller Based Real-Time MaximumPower Point Control Of Photovoltaic System, Science Direct (2009).

[3] F.Almonacid, C.Rus,P.J .Perez, L.Hontoria, Estimation Of The Energy Of PV Generator Using Artificial Neural Network, ScienceDirect(2009).

[4] Yusuf Oner, Engin Cetin,Harun Kemal Ozturk,Ahmet Yilanci, Design Of Three Degree Of Freedom Spherical Motor For Photovoltaic-Tracking Systems, Science Direct (2009).

[5] Yulin He, Xinping Chen, Wind Turbine Generator System. The Supply Chain In China :Status And Problems, Science Direct (2009).

[6] Wissem Zghal, Gueorgui Kantchev, Hedi Kchaou, Optimization And Management Of Energy Produced By A Wind Energizing System, Science Direct (2010).

[7] Y.-M. Chen, S.-C Hung,C-S.Cheng, and Y.-C.Liu , Multi-Input Inverter For GridConnected Hybrid PV/Wind Power System, IEEE (2005).

[8] Chian-song Chiu , T-S Fuzzy Maximum Power Point Tracking Control of Solar Power Generation Systems.
[9] Muldi Yuhendri, Mochamad Ashari , dan Mauridhi Hery Purnomo , Maximum Output Power Tracking dengan Metode Direct Field Oriented Control Pada Pembangkit Listrik Tenaga Angin Stand Alone, Seminar Nasional XIV - FTI-ITS (2009)

[10] Soedibyo, Feby Agung Pamuji and Mochamad Ashari, "Grid Quality Hybrid Power System Control of Microhydro, Wind Turbine and Fuel Cell Using Fuzzy Logic", International Review on Modelling and Simulations (I.RE.MO.S), Vol 6, No 4, Agust 2013, pp 1271 - 1278, Indexed in Scopus, ISSN : 1974 - 9821 / e-ISSN : 1974 - 983X

[11] Dedy Kurnia Setiawan, Mochamad Ashari, Mauridhi Hery Purnomo, "Modified Synchronous Reference Frame untuk Pengendalian Inverter Empat Lengan pada Sistem Hibrida Generator Diesel dan Battery dengan Beban Tidak Seimbang", JITEE (Journal of Information Technology and Electrical Engineering), vol. 2, no. 1, April 2010.

\section{Biodata Penulis}

Feby Agung Pamuji, memperoleh gelar sarjana dari Institut Teknologi Sepuluh Nopember (ITS) Surabaya, Indonesia pada tahun 2009. Pada tahun 2012, dia memperoleh gelar megister dari ITS, dia bergabung di ITS sebagai staf pengajar pada tahun 2012 .

Soedibyo, memperoleh gelar sarjana dan megister dari Institut Teknologi Sepuluh Nopember (ITS) Surabaya, Indonesia, pada 2013, dia memperoleh gelar doktor dari ITS, penelitiannyan di ITS dengan topik "optimization and control of hybrid power system involving diesel engine, micro hydro, wind turbine and fuel cell system". 